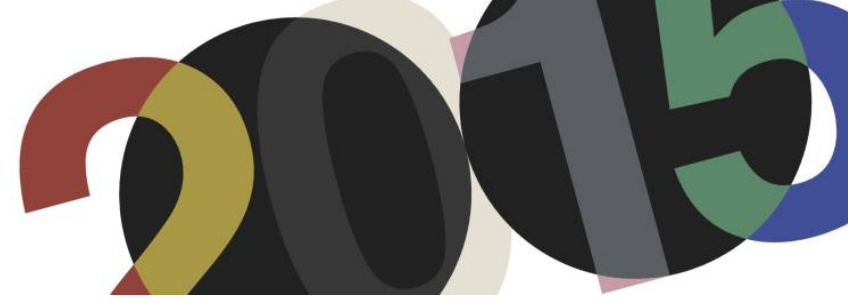

DOI: http://dx.doi.org/10.4995/LC2015.2015.911

\title{
Le Corbusier between sketches. A graphic analysis of the Acropolis sketches
}

\section{S. Harris}

Escuela Superior de Arquitectura de Barcelona, UPC

\begin{abstract}
In contrast to Le Corbusier's later written accounts and the opinions critics have formed from these texts, this article concentrates on the ideas and opinions Le Corbusier developed in-situ during his first visit to the Acropolis in 1911. Using a detailed method of graphic analysis, this research deconstructs a set of Le Corbusier's original sketches of the Acropolis made in Carnet 3 during his Voyage d'Orient in 1911. Comparing them in chronological sequence reveals how the ideas of the architect evolved whilst he was immersed in the physical experience of the Acropolis.

The article focuses on two themes prevalent in the sketches and also in his later work: The various relationships between architecture and ground; and the representation of dynamic spatial experience across time and space. It finds that Le Corbusier used in-situ sketching as an intentional and rigorous method to analyse the Acropolis, actively forming his opinions through experimentation and refinement rather than merely illustrating pre-established ideas.

This analysis reveals how Le Corbusier made use of his prior knowledge of the Acropolis but also, how he used his sketches to gradually transform this into a personal and original interpretation of the site and its buildings. It also shows that a number of his most celebrated ideas are not present in these sketches and may have developed in retrospect under the influence of other authors.
\end{abstract}

Resumen: Este artículo se centra en las ideas y opiniones de Le Corbusier desarrolladas in-situ durante su primera visita a la Acrópolis en 1911 y contrasta con escritos posteriores del propio Le Corbusier e historiadores de estos textos. Este artículo deconstruye una serie croquis originales dibujados por Le Corbusier en el Carnet 3 de su Viaje al Oriente a través de un análisis gráfico detallado. Comparando sus croquis originales en secuencia cronológica revela como las ideas del arquitecto evolucionaron mientras que estaba inmerso en la experiencia física de la Acrópolis.

El artículo se enfoca en dos temas predominantes que son presentes tanto en los croquis como en su obra posterior: Las relaciones entre la arquitectura y el terreno; y la representación de la experiencia espacio-temporal del conjunto arquitectónico. El artículo argumenta que Le Corbusier utilizaba sus croquis in-situ como método intencional y riguroso para analizar la arquitectura formando sus opiniones por experimentación y refinamiento más que para ilustrar conceptos preestablecidos.

Este análisis muestra como Le Corbusier aprovechaba sus conocimientos previos de la Acrópolis, además de transformarlos gradualmente por medio de sus croquis en una interpretación personal y original del lugar y de la arquitectura. También explica que varias de sus ideas más celebradas no están presentes en estos croquis y que las desarrolló retrospectivamente bajo la influencia de otros autores.

Keywords: Le Corbusier; Sketch; Acropolis; Graphic analysis; Voyage to the Orient.

Palabras clave: Le Corbusier; Croquis; Acropolis; Análisis gráfico; Viaje al Oriente.

\section{Introduction}

From the start of his career up to his final projects, his sketches provide an extremely direct and personal window onto his thought process, both when reflecting on his own ideas and when reacting to those he observed around him. Le Corbusier's sketches are not only records of his thoughts and opinions, but in fact formed his ways of thinking. These were often minimal, fast and emotive sketches with which he perfected both his analytical and design ideas. His sketches allow an incomparable insight into his developing opinions and his method of research. This article investigates a turning point in Le Corbusier's formation as an architect, through analysing a set of the sketches he made on his first visit to the Acropolis in 1911 which are recorded in their 
original order in the Carnet 3 of the Voyage d'Orient ${ }^{1}$. This differs from the copious literature ${ }^{2}$ on this particular visit both in its approach and results. It treats his sketches as the evolving record of a learning process rather than as clear statements of definitive opinions. By applying a novel and detailed method of graphic analysis, the sequence of exploratory sketches reveals the growth of Le Corbusier's ideas and how he went about "designing" his interpretations of the Acropolis, its setting and its temples. This method allows a new appraisal of Le Corbusier's visit based exclusively on concurrent and in-situ sources, in contrast to the many accounts in the literature which focus instead primarily on his largely retrospective writings. The article also presents a range of ways in which Le Corbusier manipulated his sketches in order to develop and radicalise his opinions. This uncovers Le Corbusier's graphic techniques underlying his analysis and design, revealing his highly intentional but also flexible and experimental method.

Of all the buildings Le Corbusier studied during his Voyage to the East, it appears that his visit to the Acropolis was a revelation to the young architect and fundamentally altered his way of thinking about architecture from then on. The dramatic change in Le Corbusier's architectural thinking at this moment is described by Jacques Lucan $^{3}$ and referred to as a step change by Geoffrey Baker ${ }^{4}$. Le Corbusier himself referred back to his experience of the Acropolis so often that J-L Cohen refers to it as a kind of "Acropolis syndrome". Given the significance of the ideas which emerged during his visit on his later work, both theoretical and built, it is interesting to consider how his thoughts emerged and developed during his time in contact with the monument. This may shed light on his process of learning about precedents and appropriating architectural ideas.

Most scholars have based their research primarily on Le Corbusier's own writings about his visit, however most of these were in fact written in retrospect ${ }^{6}$ and influenced to varying degrees by his later reflections and the theories of others. Apart from a few brief written notes and letters, the only concurrent record of his analysis in situ are photographs and a group of sketches. The set of sketches in Carnet 3 in particular give a glimpse of his direct and immediate reaction to architecture and sense of place, however, until now, these have not been thoroughly studied in detail from a graphic perspective.

This article contributes to the existing literature through charting the intellectual metamorphosis which took place during his intense study of the Acropolis in 1911 and questions what sequence of reasoning his ideas went through $^{7}$ and how the sketches in fact determined the direction of his thoughts.

\footnotetext{
${ }^{1}$ Corbusier, L.: Voyage d'Orient : Carnets. Milano : Mondadori. 2002. Facsimile reproduction of the original carnets.

${ }^{2}$ Amongst the main authors are Allen Brooks, Kenneth Frampton, Geoffrey Baker, J Lucan, J-L Cohen and Ricardo Daza. See the Bibliography for further references.

${ }^{3}$ Lucan, J. : Le Corbusier : une encyclopédie. Paris : Centre de Création Industrielle. 1987. pp.20-22

${ }^{4}$ Baker, Geoffrey: Le Corbusier - the creative search - the formative years of Charles-Edouard Jeanneret. New York: Van Nostrand Reinhold, 1996. pp174-187

${ }^{5}$ Cohen, J.-L.: "Vers Une Acropole: d'Athènes a Ronchamp". In Le Corbusier - L'Invention d'un architecte Paris : Fondation Le Corbusier. 2014. p388

${ }^{6}$ Ibid. pp377-384. Brooks, Allen: Le Corbusier's Formative Years: Charles-Edouard Jeanneret at La Chaux-de-Fonds. Chicago: University of Chicago Press. 1999. pp279-285. Moos, S. von. Le Corbusier : elements of a synthesis. Rotterdam : 010 Publishers. 2009 pp30-34.

${ }^{7}$ Daza Caicedo, R., \& Quetglas, J.: Tras el viaje de Oriente: Charles-Édouard Jeanneret-Le Corbusier. Barcelona : Fundación Caja de Arquitectos. 2015. Ricardo Daza provides a comprehensive account of Le Corbusier's Voyage to the Orient, accompanying an explanation of his typical daily visits to the Acropolis with Le Corbusier's texts, and other sources from the time.
} 
The importance of this research lies first in the method of graphic analysis used to deconstruct the original sketches revealing their underlying logic and second, in the insights into his method of reasoning which this analysis of the sketches reveals.

The hypothesis is that the sketches focus on different themes to those often discussed from Le Corbusier's later texts, and which reflect his immediate preoccupations whilst in direct contact with the Acropolis. This research shows that he used sketching to actively investigate and learn rather than just to memorise what he saw. In fact various themes crucial to his later work are not only illustrated, but were actively developed in-situ through using his sketches to experiment with and refine his analysis ${ }^{8}$. Combining his prior knowledge with direct observation, the process of sketching on location helped to transform his thoughts into original interpretations of the essence of classical architecture and discover its new relevance to twentieth century architecture. This leads to a number of conclusions regarding the focus of Le Corbusier's thoughts when on location which extend, and in certain respects contrast with, the prevailing views about the influence of the Acropolis on his later work.

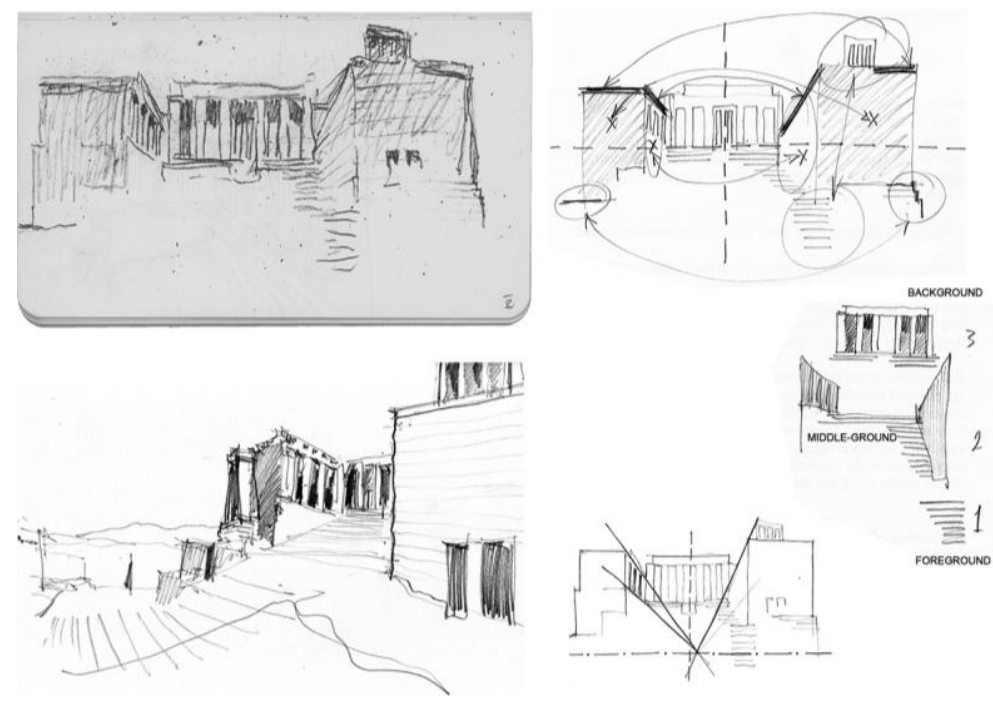

1. Examples of graphic analysis of sketch 107, Carnet 3, Voyage d'Orient. Clockwise from top left: Le Corbusier, Sketch 107, Carnet 3, Voyage d'Orient, 1911.; Propylaea, author's in-situ sketch 2014 for comparison with 107; Composition analysis of original sketch 107 (SH); Depth of field analysis (SH); Perspectival analysis (SH).

This analysis compares the set of original sketches of the Acropolis in the Carnet 3 of the Voyage d'Orient, following a method of graphic analysis based on that used by Josep Quetglas in his organisation of the Villa Savoye drawings ${ }^{9}$. Due to the fact that they are preserved in chronological order, and share equivalent formats and similar content, the set may be compared and contrasted with an unusual degree of precision. Two particular architectural themes have been selected for the following analysis: the relationship between architecture and the ground, and the dynamic experience of architectural space through movement. These have been selected for two reasons: First, for the importance Le Corbusier attributed to them in both the Acropolis and his own work ${ }^{10}$; and

\footnotetext{
${ }^{8}$ Due to their order in the Carnets, these have been preserved in their most likely original order. The sequence of sketches chart the evolution of his interpretations of the architecture and show that in contrast to Baker's opinion (Baker. Op.Cit.p182) that Le Corbusier used drawing to imprint images on the mind (after the manner of his teacher l'Eplattenier), Le Corbusier's method of drawing on the Acropolis in particular, fast, excited, exploratory sketches served to actively propel his reasoning forward more than merely recording and memorising fixed conclusions.

${ }^{9}$ Quetglas, J : Les Heures Claires. Barcelona : Massilia. 2008

${ }^{10}$ Corbusier, L.: Ed. Boesiger, W.: Oeuvre Complète. Paris : Éditions d'architecture. 1965
} 
second because their influence on each one of these carnet sketches can be clearly seen to evolve throughout the sequence. In order to compare like with like and minimise the number of variables between drawings ${ }^{11}$, the original sketches have been redrawn by myself in the form of diagrams to enable clear and direct comparison across the range of sketches and viewpoints. Each set of diagrams focuses on specific graphic characteristics of the sketches and reduces the information in each sketch to its essential minimum. These analyse the graphic construction of the sketches, focusing on changes in composition, scale, proportion, perspective and view point, context, spatial continuity and depths of field (foreground, middle-ground and background), as well as the various drawing techniques Le Corbusier used, including different qualities of line and shading. Comparing the resulting diagrams in chronological sequence shows the direction in which his thoughts moved and the degree to which they changed.

In outline, this research finds that variations in the way Le Corbusier represented important relationships between architectural elements and their surroundings reflect a continuous process of experimentation through which he refined his conceptions of the Acropolis and its temples. Whilst these were sometimes inspired by his prior knowledge, the ideas underlying the sketches always took a course of their own developing along unexpected conceptual paths through trial and error and continual revision. Although Le Corbusier's ideas about the Acropolis continued to evolve significantly during the years after his visit, several patterns emerge in the carnet sketches showing his ideas at the time were converging towards certain clear architectural concepts regarding the relationship of architecture and ground, and the representation of movement and spatial sequence. But it finds that a number of Le Corbusier's later theories were absent from his thoughts. This suggests that many of the ideas stated in his later texts were either not at all clear to him whilst on location, or were simply not present amongst his concerns at the time when confronted by the physical presence of the Acropolis. Significant themes in Le Corbusier's later work that are notably absent include mathematical precision, number and measure, historical imagination, precise plastic form and natural light ${ }^{12}$. The promenade architecturale (the observer's pathway through the built space) does not follow as directly from Choisy as Le Corbusier's later writings may suggest ${ }^{13}$. It shows an appreciation of distinct, immersive spatial environments arranged in order, but not a stipulated path connecting a set of fulcrum viewpoints in the manner of Choisy ${ }^{14}$. This article separates his actual discoveries in-situ from his prior knowledge and ideas he appropriated from others, from later influences and from his retrospective thoughts, and traces the course of his original in-situ analysis of the Acropolis.

The article is organised in the following way. First, the relationship between architecture and ground, and the role of various types of platform and plinth is discussed. The second section considers the role of movement in Le Corbusier's representation of the Acropolis. The final section draws conclusions about Le Corbusier's use of sketching from the results of the detailed analysis of his in-situ sketches.

\footnotetext{
${ }^{11}$ Thompson, D. Wentworth: On Growth and Form. Cambridge: Cambridge University Press. 1961 (abridged edition) pp.268-276

${ }^{12}$ Frampton, K.: Le Corbusier. London: Thames and Hudson. 2001. p14. Frampton cites "L'Art de Demain" by Henri Provensal (1904), which was later paraphrased by Le Corbusier in Vers Une Architecture, (1922)

${ }^{13}$ Corbusier, L.: Vers Une Architecture. Paris. 1923. Reprinted as Towards a new architecture. London : Architectural Press. Translation by Etchells, F. 1987

${ }^{14}$ Choisy, A: Histoire de l'architecture. Paris. 1899
} 
Original sketches by Le Corbusier are referred to by the page number in the Carnet 3 from the Voyage $d^{\prime}$ 'Orient ${ }^{15}$. All other sketches and diagrams are by the author $(\mathrm{SH}$, the author's initials, is written in the captions).

\section{Architecture, base and ground.}

From the first to the last sketches of the Acropolis in Carnet 3, the relationship between natural ground, built architecture and the various man-made levels in between, is of central importance. Of the few elements consistently portrayed, the parts which either separate or join the ground with the principle buildings are repeatedly given great visual significance and considerable variety in their graphic treatment. Le Corbusier experimented with a series of alternative combinations of temple and ground before reaching a definitive conclusion in his final sketches. His writings also confirm this interest in the connection between temple and ground, especially in the degree of separation or integration between the two and what effect this may have on the perception of the temple in its context ${ }^{16}$.
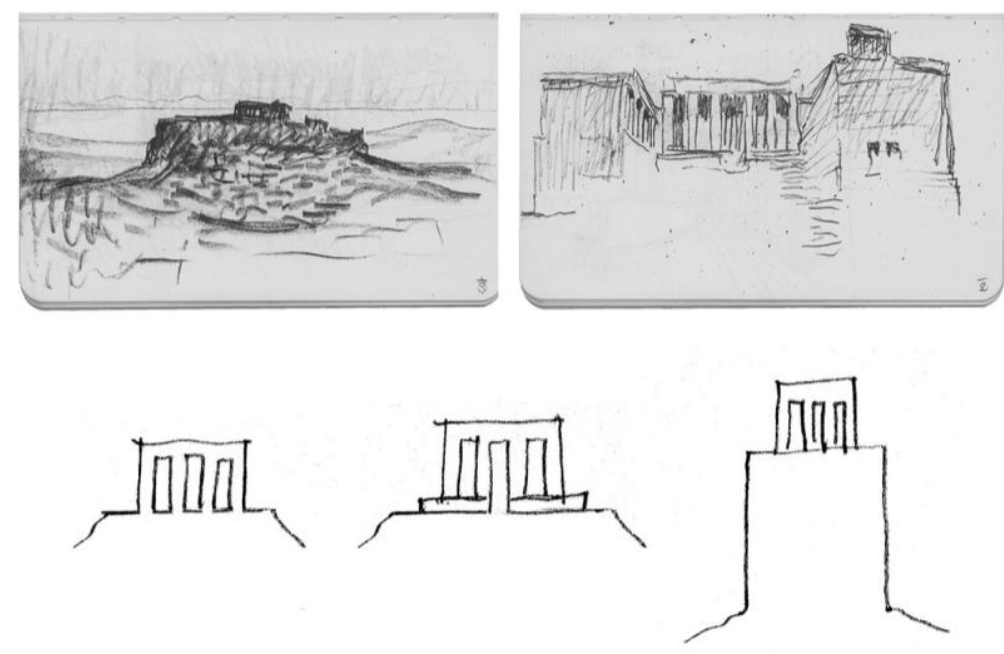

2. Clockwise from top left: Le Corbusier, Sketches 103 and 107, Carnet 3, Voyage d'Orient, 1911.; Schematic diagrams (SH) showing developing variations in relationship of temples and ground in sketches 103 and 107.

Through reducing the sketches to diagrams of ground, building and the intermediate layer, it may be seen that Le Corbusier's reasoning was influenced by several factors.

First, in the degree of connection or separation between temple and ground. In the sketches seen from the distance, temple, base and ground are all fused together as one single element. Although 98 shows a tonal emphasis on the central Parthenon, 103 and 104 show the Parthenon, Acropolis and the hill itself as a single mass. This idea is repeated in his written notes about the visit published in $1966^{17}$. From sketch 109 onwards, the horizontal steps become an extremely important part of the sketches separating the temple from the ground and

\footnotetext{
${ }^{15}$ Corbusier, L.: Voyage d'Orient : Carnets. Milano : Mondadori. 2002. Facsimile reproduction of the original carnets.

${ }^{16}$ Corbusier, L.: 1923. Op.cit.: p.208

${ }^{17}$ Corbusier, L.: Le voyage d'Orient. Paris : Ed. Parenthèses. 1966. p.166-7. However, the poetic description was written later and appears to describe the in-situ sketches so precisely as to suggest that it was written later using the sketches as an aide memoire and hence simply recapitulating the conclusions drawn in the carnets.
} 
its context. These repeated sets of horizontal lines focus attention on the temple above by literally underling it. Sketches 111 and 113 show the temple of Athena Nike presented as if it were a sculpture on a pedestal, emphasising the separation of temple from ground in the same way that the sculptures drawn in 117 and 119 are elevated and isolated by their plinths (figure 3). This is confirmed in the following pages by notes about sculptures on pedestals.
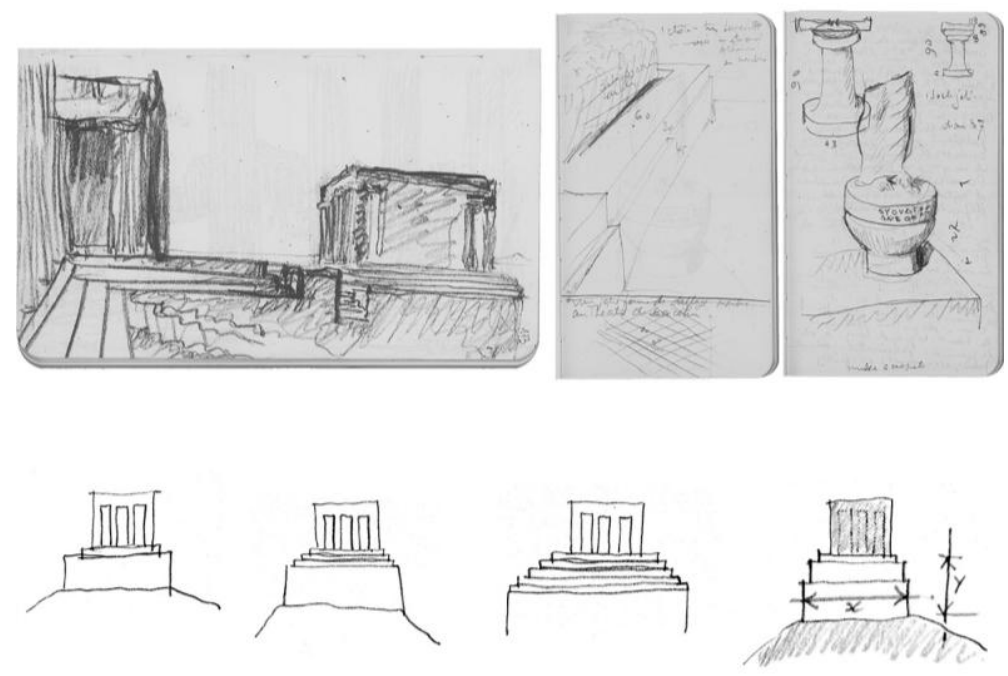

3. Clockwise from top left: Le Corbusier, Sketches 113, 117 and 119, Carnet 3, Voyage d'Orient, 1911.; Schematic diagrams (SH) showing developing variations in relationship of temples and ground from sketches 109 to 119.

Second, the use of steps to change the level of the observer's viewpoint. Le Corbusier was certainly interested in the complexity of the ground-levels on the Acropolis, and had already studied how the Erechtheion made use of different levels to create different temples out of a single building. Rather than repeat what he already knew (as shown by the ink section through the Propylaea copied from Choisy's drawing the previous year ${ }^{18}$ ), in sketches 106-113, Le Corbusier chose not to draw the ramp through the Propylaea threshold, but showed the changes in level through the repetition of steps and shading on plan. These steps were drawn approximately, but with increasing emphasis as the sketches continue (fig 6, sketch 111). Their precision was less important than the fact that they demonstrated the change of level which mattered to Le Corbusier for the effect this had on the visitor's perception of the building and landscape ${ }^{19}$. This may be seen in the upward facing viewpoint of 107 and the drawing's position at the top of the page emphasising the height of the entrance and its effect on the spatial sequence (figure 1).

Third, this set of horizontal lines creates a relationship with the distant horizon, in effect creating a foreground horizon line. See for example the very slight difference in height between 111 and 113 which gives 113 a closer relationship between the horizon line and the horizontal lines of steps, without quite touching so as to remain visible (figure 6). In Sur l'Acropole ${ }^{20}$, Le Corbusier states how the steps connect on to the horizon. The stylobate steps also emphasise the contrast between the horizontal lines of the steps and the architrave and the vertical

\footnotetext{
${ }^{18}$ See the section in ink of the Propylaea (FLC1784) and plan of the Erechtheion (FLC 1785). Daza (Op.Cit. 2015).

${ }^{19}$ Baker quotes Le Corbusier's description of the oversize steps of the Parthenon. Baker (Op.Cit. 1996) p175

${ }^{20}$ Corbusier, L. Sur L'Acropole. 1926 in Corbusier, L., \& Duboy, P.: Croquis de voyages et études. Paris: Quinzaine littéraire - Louis Vuitton. 2009
} 
columns sandwiched in between, whose verticality is optically emphasised by the fluting as well as by the entasis of their sides, as seen most clearly in 113 .

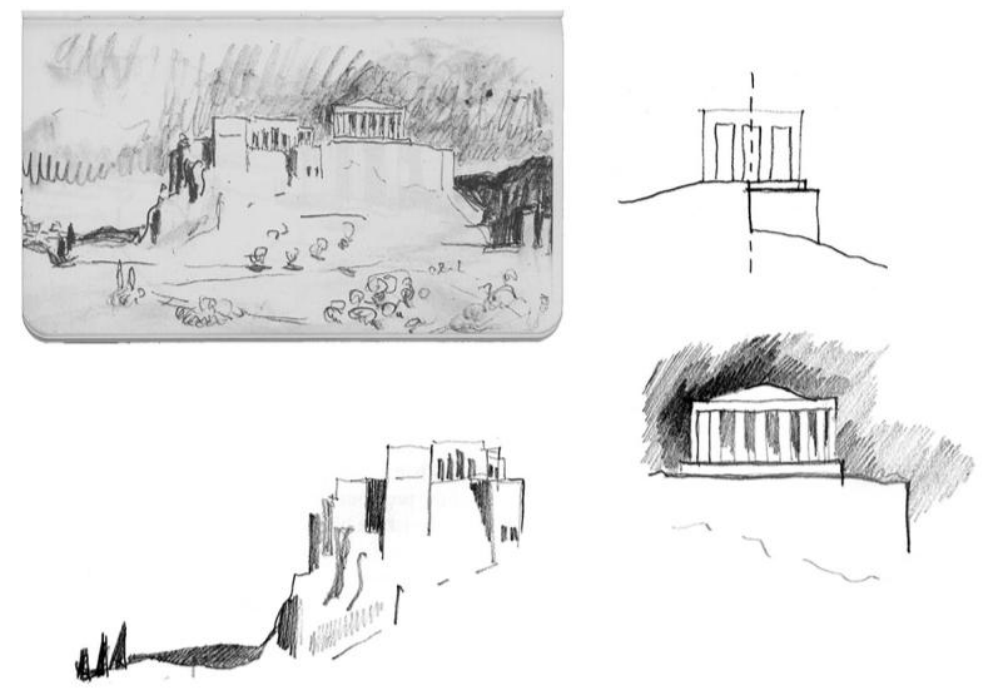

4. Clockwise from top left: Le Corbusier, Sketch 123, Carnet 3, Voyage d'Orient, 1911.; Schematic diagrams of 123 (SH) showing integration of cliff and buildings to the left and the Parthenon separated from the ground by its plinth on the right.

However various important themes in Le Corbusier's later work (in his writings and projects) which are often traced back to his first visit to the Acropolis, do not appear in his carnet sketches. Frampton states that Le Corbusier's sketches are full of measurement and annotations, whilst these specific sketches are not, and in places they even contain significant artistic license over number and proportion such as in the colonnade of $113^{21}$. According to Baker, Le Corbusier believed perfection in the Acropolis came down to mathematics and measure, not just the interaction of geometric shapes ${ }^{22}$. But whilst Le Corbusier does mention the mathematical precision of the stone-cutting in Sur L'Acropole, he made no attempt to convey this in his sketches. Although plinths and pedestals from elsewhere in Athens have been measured precisely and noted (as in 117 and 119), the steps in the carnet sketches are drawn emphatically, but often so hastily that mistakes with vanishing points often occur and the proportions and number of steps is usually approximate (Figure 6 sketch 111). However, this approach differs from Le Corbusier's written descriptions of precise measurements, proportions and optical adjustments, smoothness, and fineness of jointing ${ }^{23}$. Instead, architectural proportion is sketched only very approximately, and is in some cases deliberately modified in order to better illustrate other issues of greater interest to him whilst in situ (figure 6, sketch 113). The nature of the small, fast, soft pencil sketches does not lend itself to exact renderings of the precision of the stone masonry, nevertheless, he drew mouldings, fluting and occasionally entablatures in a deliberately impressionistic manner (see the carefully conceived and repeated watercolours of the Parthenon columns ${ }^{24}$ ).

Furthermore, although some authors trace the inspiration behind Modulor man back to the Parthenon, there is no direct evidence of this in the carnet sketches, and no specific reference made to human scale, and so this idea might seem to have been developed later and been related back to the Parthenon in retrospect. Rather than

\footnotetext{
${ }^{21}$ Email from K. Frampton to the author, 29/6/2011 "Le Corbusier's sketches invariably carry data and dimensions."

${ }^{22}$ Baker, G. Op.cit.; p181

${ }^{23}$ Corbusier, L. Op. cit. Vers Une Architecture and Sur l'Acropole.

${ }^{24}$ Daza, R. Op. Cit. : p. 273
} 
technical execution, Le Corbusier appears to have been interested most of all in the effect the plinth had on the relationship between temples and place - at first with the ground immediately beneath and later with the far horizon. Although he was specifically conscious of all these matters, as his earlier drawing of the corner columns of the Parthenon shows ${ }^{25}$, they were not of prime interest to him when on location.

The set of sketches trace the development of these ideas through a series of graphic experiments and variations. They show Le Corbusier's vision of architecture and ground diverging towards two conclusions: on the one hand fusing them both together, and on the other, emphasising steps and plinths in order to separate them clearly. Both versions are combined in different parts of sketch 123 connecting the Propylaea and its buildings to the cliff top (figure 4 left), whilst separating the Parthenon high up on its own plinth (figure 4 right).

\section{Movement}

The carnet sketches show how Le Corbusier developed his ideas of space experienced in motion and across time. This was one of the first times where he took particular interest in architecture organised according to the observation of a viewer moving progressively through a sequence of spaces. Whilst the initial sketches form picturesque compositions of the Acropolis seen from the distance in a relatively traditional arrangement, reminiscent of landscape painting from the previous century, the later sketches increasingly imply movement and spatial progression. This is a gradual but important change in how space is represented, which may have sprung initially from his prior knowledge of the theories of Choisy, but then developed through a process of trial and refinement as the sketches progressed. Given the importance of the promenade architecturale in Le Corbusier's later work, and his direct quote of Choisy's explanation of the Acropolis in Vers Une Architecture ${ }^{26}$, it is interesting to question to what degree these ideas were influenced by his prior knowledge of the theories of others, and to what degree he transformed them into his own interpretations by means of his investigative sketches whilst he was physically present on the Acropolis.

Although the ideas develop gradually through experimentation from one sketch to the next within each group, this process can be seen to evolve in three main stages. The first of these groups $(98,103,104)$ demonstrates a comparatively "picturesque" stage. The second (106-115) starts with a close interpretation of Choisy's theory of picturesque sequence but gradually transforms this into an individual and original interpretation of space. The third group $(123,125)$ shows a mature stage where each sketch implies spatial progression through the "dynamic" composition of the image.

\subsection{Sketches 98-104}

The first group, sketches 98, 103 and 104, concentrate on describing the Acropolis in its context which is reduced to a minimal selection of surrounding elements. The three sketches show distant views of the Acropolis from Mount Lycabettus to the North. The principle variation is the scale of the Acropolis in relation to the page and its position within the frame. This has the effect of changing the relationship of the Acropolis to its context. Although all three follow the same picturesque structure, they develop increasingly complex depths of field, progressively shifting the focus of the sketches towards the relationship between the Acropolis and its setting in the landscape.

\footnotetext{
${ }^{25}$ Brooks, A. Op. cit; p284

${ }^{26}$ Corbusier, L.: Vers Une Architecture. Paris. 1923. Reprinted as Towards a new architecture. London : Architectural Press. Translation by Etchells, F. 1987. p52
} 

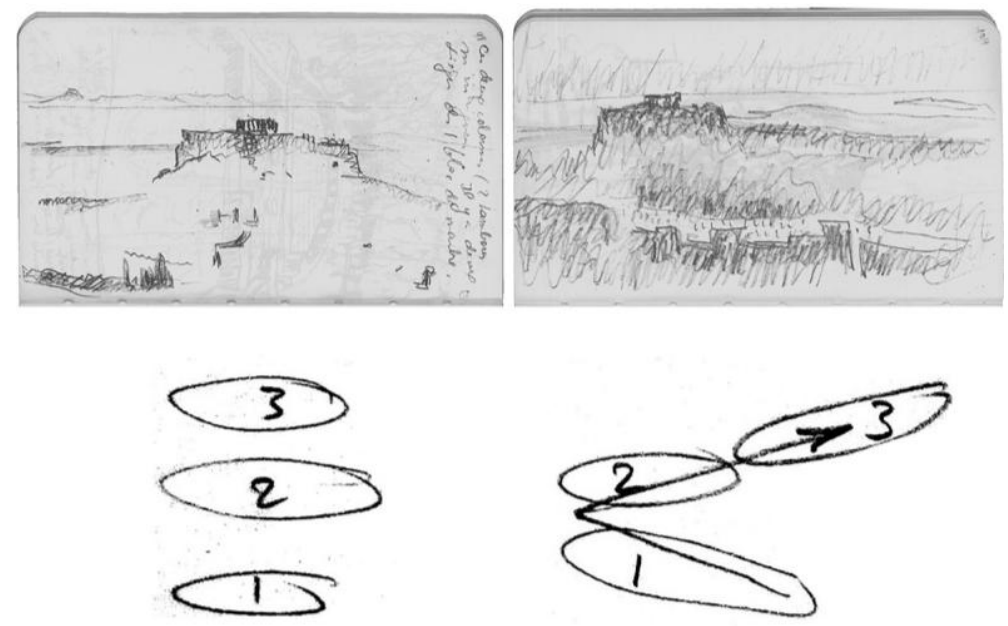

5. Clockwise from top left: Le Corbusier, Sketches 98 and 104, Carnet 3, Voyage d'Orient, 1911.; Schematic diagrams (SH) showing developing variations in depths of field in the above sketches.

Each view is comprised of three receding planes (depths of field), foreground ("1"), middle-ground (“2”) and background (" 3 "), each of which may be either continuous, joined on to one of its neighbours, or discontinuous from other fields within the drawing. Different arrangements of these regions dramatically juxtapose the architecture with other selected elements of the landscape or context. The relatively picturesque structure of 98 places the Acropolis in the middle ground between abstract foreground shapes and the distant horizon (figure 5). The three regions are isolated vertically up the page ${ }^{27}$. This structure evolves in the third sketch (104) which arranges the three regions diagonally and begins to suggest movement across the page. As opposed to the comparatively flat and simultaneous perception of the three depths in 98, the diagonal spatial structure of 104 begins to lead the viewer's eye through the drawing past the Acropolis and into the background. The sense of movement through space which this implies is developed further in the following sketches and is echoed by Le Corbusier's written description of the view ${ }^{28}$.

\subsection{Sketches 106-115}

The second group, sketches 106, 107, 109, 111, 113 and 115, focus on the entrance to the Acropolis through the main gateway, the Propylaea. The first of these demonstrate the influence of Le Corbusier's prior knowledge on his understanding of the Acropolis. In the Histoire de L'Architecture ${ }^{29}$, published some twelve years before Le Corbusier's visit, Auguste Choisy had explained the irregular arrangement of the architecture on the Acropolis in terms of the experience of the viewer approaching, entering and moving between the buildings. It seems that Le Corbusier visited the Acropolis with these ideas already firmly established and it is often considered that they became strong personal convictions on account of his research in-situ. However, a detailed look at the sketches

\footnotetext{
${ }^{27}$ Many 19th century watercolours of the Acropolis by artists such as E. Lear, L.Lange, and W. Turner show equivalent picturesque structures where by the Acropolis fades into the background providing an idyllic classical backdrop for the foreground scene.

${ }^{28}$ Le Corbusier describes the scene at dusk with the daylight fading over the Peloponnese and the lights beginning to brighten the city below. The Acropolis reminds him of an ocean liner heading out across the "sea" of the Athenian plane. This impression of virtual movement corresponds with the new dynamic arrangement of the landscape in 104. Corbusier, L.: Le voyage d'Orient. Paris : Ed. Parenthèses. 1966. p166-7.

${ }^{29}$ Choisy, A. Op. cit.
} 
in chronological order suggests that although Le Corbusier started off with these ideas, he rapidly transformed them into original interpretations of his own.
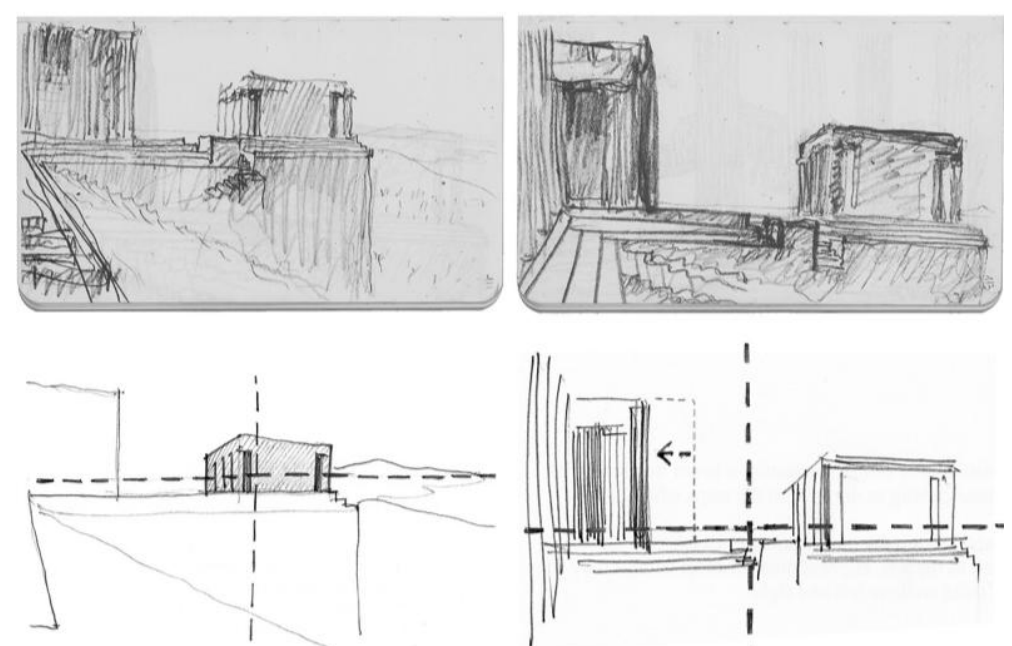

6. Clockwise from top left: Le Corbusier, Sketches 111 and 113, Carnet 3, Voyage d'Orient, 1911.; Diagrams (SH) showing differences in composition and central focus of the image. Diagram 113 (bottom right) also shows the removal of one bay in the original sketch.

According to Choisy, the viewer's perception of the Parthenon is built up through a carefully choreographed sequence of views along the approach route, each of which leads on to the next building up the drama of the spatial experience. Choisy explains this through a set of images (his own reconstructed illustrations) in the manner of stills from a cinematic storyboard. These images are static in the sense of being still frames within a sequence, but a sense of movement is generated by seeing each image one after another. In Vers Une Architecture, Le Corbusier refers to this architectural arrangement on the Acropolis as excellent "stagemanagement" and illustrates his text with Choisy's own drawings ${ }^{30}$. In the late 1930s, the filmmaker Sergei Eisenstein also saw parallels between Choisy's explanation of the arrangement of buildings on the Acropolis with his own experience of film making through splicing together sections of footage ${ }^{31}$. In his essay "Towards a Theory of Montage", he explains how a set of images seen one after another create meaning depending on the order in which they are seen. Motion is implied by the sequential order of the images. In terms of Choisy's illustrations, movement occurs between the drawings and not within them. As Eisenstein describes in terms of cinema, Choisy had also described a storyboard made up of a sequence of framed views each of which was complete in its own right, but when seen together formed a highly choreographed route through the complex.

Le Corbusier starts his own analysis in sketches 106 and 107 from the same point of departure as Choisy, facing up towards the entrance steps of the Propylaea (figure 1). Sketch 107 echoes Choisy's first view extremely closely implying that Choisy's illustration and theory of movement in the arrangement of the Acropolis spaces were initially at the front of his mind. However the following sketches do not copy Choisy's other critical viewpoints so closely, but instead depict a different interpretation of the spatial sequence. J-L Cohen mentions

\footnotetext{
${ }^{30}$ Corbusier, L.: Vers Une Architecture. Paris. 1923. Reprinted as Towards a new architecture. London: Architectural Press. Translation by Etchells, F. 1987. p52

${ }^{31}$ Interestingly, Eisenstein also illustrates his explanation with very simple sketch diagrams showing the sequence of views on the Acropolis as if they were the frames of a film. See Eisenstein, S.: Towards a Theory of Montage. London : British Film Institute. 1994. Original essay 1937-40 published posthumously.
} 
the cinematographic arrangement of the sketches relating to the entrance Propylaea ${ }^{32}$ (sketches 107-115) panning around from the north to south-west to south. Although 109-113 do resemble sections of a panoramic view, the repetition and distortion of 113 (figure 6) show that Le Corbusier was also trying to explain the different attributes of the spatial ensemble. The sketches describe the overall spatial environment through which the visitor passes, incorporating the impressions of volume, mass, distance and material on all sides rather than just the sequence of masses appearing consecutively in front. Rather than follow the direction of movement, as in a film, using visual cues to lead from one frame to the next, Le Corbusier instead drew a set of views facing outwards, sideways and backwards when he reached the threshold of the Propylaea. The impression of the visual sequence is lost if a backwards facing view (in other words, of the exit) is spliced into the entrance progression. The following sketch 115 moves still further away from Choisy's perspectives and shows that Le Corbusier was by then no longer intending his set of sketches to repeat the same storyboard of sequential views. Instead, he drew a view facing out of the Propylaea directly towards the Western front of the Parthenon, ignoring the rest of Choisy's illustrations leading towards the Caryatids and around the Parthenon. This decision demonstrates that by sketch 115, Le Corbusier was now using his sketches to explore what he found and to rationalise the impressions which this evoked in him, rather than continuing to base his impressions on the ideas of others.

This change from the mere visual depiction of spaces to a more immersive exploration of space is also apparent in the difference between the two plans on page 106 (figure 7). The upper plan, most likely drawn first due to the improved proportions of the lower plan, concentrates on the number and rhythm of columns marking the threshold. The lower plan however concentrates far more on describing the volumes and masses on either side of the entrance. Whilst the first plan shows a quick sketch of the principle architectural elements in approximately correct relation, number and proportion, the second seems to be determined by Le Corbusier's direct physical experience of volume and mass and the spatial relationships between them. Tone is used to show the depth of the porticoed spaces and mark the edge of the fortifications and the drop of the cliff edge. The abstract depiction of sequence in the upper plan is replaced by direct understanding of volume and mass determined by direct physical immersive experience.

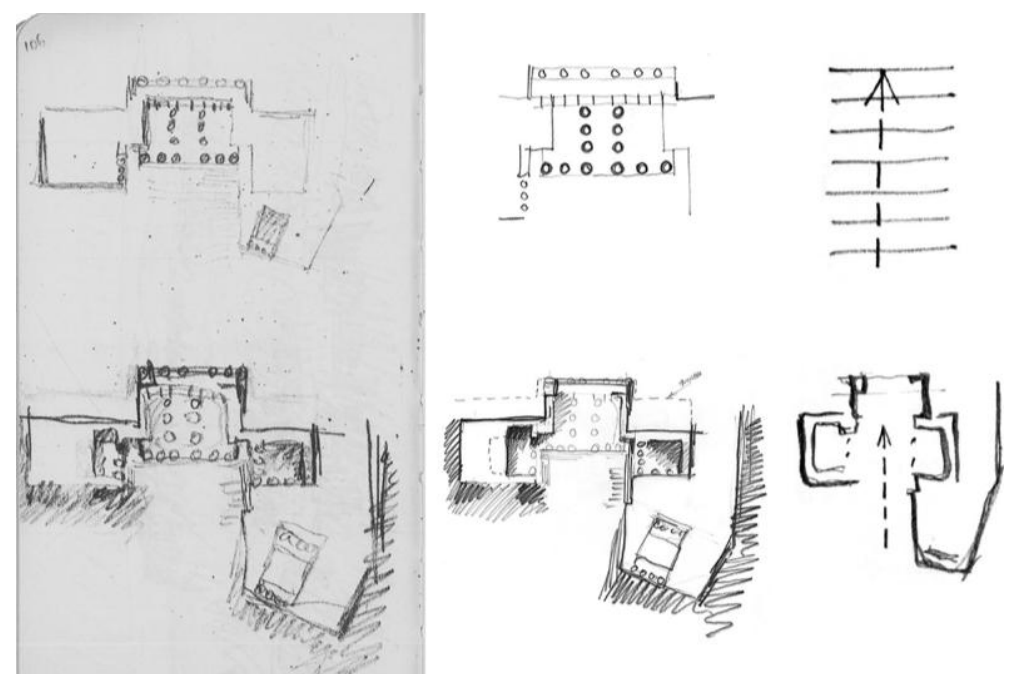

7. Clockwise from left to right: Le Corbusier, Sketches 106, Carnet 3, Voyage d'Orient, 1911.; Schematic diagrams (SH) showing different representations of number and rhythm along the central entrance axis (above), and of volume and space (below).

\footnotetext{
${ }^{32}$ Cohen, J.-L.: "Vers Une Acropole: d'Athènes a Ronchamp". In Le Corbusier - L'Invention d'un architecte Paris : Fondation Le Corbusier. 2014. p381
} 
The change in Le Corbusier's understanding of spatial depth can also be seen in the increasingly complex way in which the various depths of field are combined. Up until 111, depths of field had been arranged alongside one another, either vertically (98), horizontally (109) or diagonally (104) (figure 5). Sketch 113, however, makes a significant jump in the organisation of depth with critical consequences for the portrayal of architecture and landscape, moving from adjacent relationships to the juxtaposition of extreme differences in depth (figure 6). By leaving the centre of the drawing empty, the foreground architecture frames either side of the distant horizon, creating a dramatic counterpoint between horizontal steps and the horizon line itself $^{33}$.

However, whilst this contrast between near and far depths of field may serve to emphasise the contrast between elements such as columns and horizon, by itself it does not create a narrative sequence. Incorporating a third depth of field can generate a directional sequence of spaces, in effect, a beginning, middle and end. In the following sketch, 115 (figure 8), the foreground now not only frames the background, but is overlaid across the entire picture-plane. Background and minimal middle ground are shown through a transparent screen of the foreground portico overlaid onto the main view of the Parthenon in the distance.
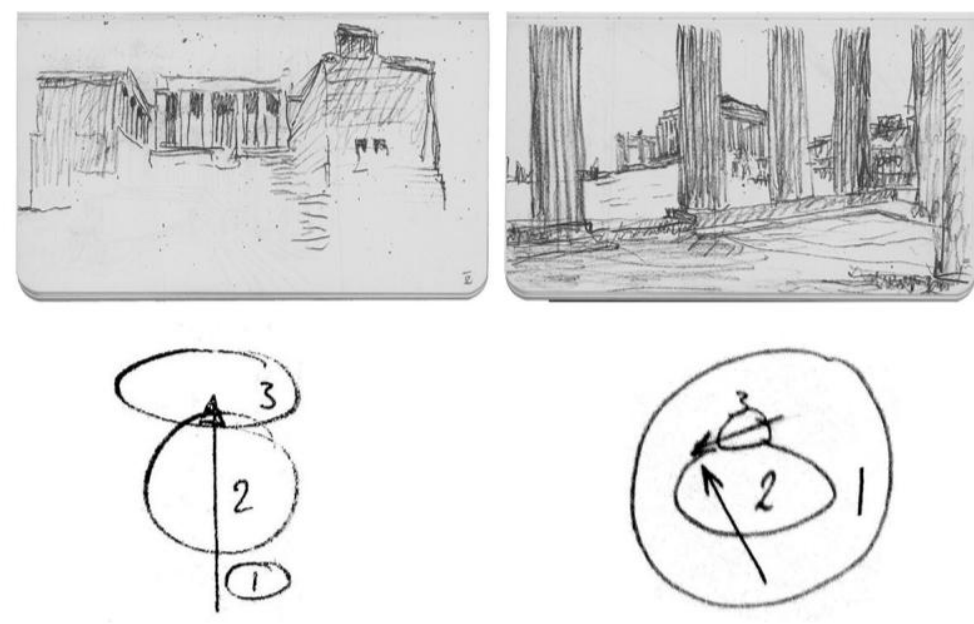

8. Clockwise from top left: Le Corbusier, Sketches 107 and 115, Carnet 3, Voyage d'Orient, 1911.; Schematic diagrams $\mathrm{SH})$ showing developing variations in depths of field in the above sketches.

\subsection{Sketches 123 and 125}

Le Corbusier saw that the apparent symmetry of the buildings was in fact made to appear that way through a great variety of asymmetrical contrivances. This way of opposing unequal parts to create an overall sense of order and balance caught Le Corbusier's interest. As the sketches progressed, he looked for new ways to express the asymmetry of the Acropolis which he appreciated was so vital to its effect on the viewer. Referring to these sketches, Allan Brooks highlights the spatial juxtaposition between masses of different size, height and transparency, and how overall this achieved a balanced asymmetry ${ }^{34}$. The compositions became increasingly

\footnotetext{
${ }^{33}$ The Propylaea portico is artificially pulled into the left of the page (by eliminating one column from the portico in front) bringing the set of buildings all into one single space.

${ }^{34}$ Brooks, A.:1999. Op.cit.: p.283 "Details were not recorded, only the relationship of part-to-part. Irregularity, not regularity, caught his eye."
} 
sophisticated in the later sketches managing to maintain a sense of order in the sketch despite the irregular arrangement of the architecture, through balancing contrasting tones, textures and qualities of line.

In contrast to the rapidity of the carnet sketches and the impressionistic quality of their lines, the compositions themselves are structured with considerable care and intention. They are composed according to a careful arrangement of regulating lines, proportion and scale, making subtle use of graphic techniques to balance dramatically asymmetric compositions. Perhaps in order to compensate for the repeated asymmetry of the spaces of the Acropolis, the graphic compositions often make use of primary geometric arrangements such as dividing pages according to the golden proportion, or balancing elements of the composition across vertical axes in the centre of the drawing (figures 9 and 10).

In the later sketches, the space of the foreground becomes increasingly important and serves to connect the viewer directly with the space within the image. Sketch 113 artificially compresses the Propylaea's southern wing by removing one of the two bays shown in 111 (figure 6).

This brings into the foreground the Propylaea portico and steps at the left of the picture frame. A variety of elements occupy the foreground in the following three sketches, creating continuous spatial regions leading from the picture plane (the apparent position of the observer) right up to the architectural focus of the sketch in the middle ground.

On the other hand, the contrast between the focal space occupied by the architecture and the distant landscape is heightened in the later sketches. This emphasises the relationship between the architecture and horizon whilst making the composition more striking and dramatic. Opposites are contrasted across a central compositional axis which not only accentuate their differences, but creates a sense of order through balancing architecture/nature, solid/void, near/far. Regions of opposite tones or contrasting textures mirror one another across the centre-line of certain drawings, giving an impression of order to an otherwise highly asymmetric composition. Such use of balanced asymmetrical compositions and drawing techniques graphically compensates for the apparent irregularity of the architectural composition.

Le Corbusier also made careful use of the graphic composition of the images to explain the architectural composition, through selecting, emphasising or minimising the different spatial relationships between various parts of the architecture, context and observer. The way the image is composed - symmetry, contrast, balance, scale, perspective, viewpoint etc - allowed him to highlight those aspects of the architecture he considered most significant. In various cases, the views have been redrawn several times in succession varying the graphic composition in order to switch the focus of the drawing onto different aspects of the same building. 


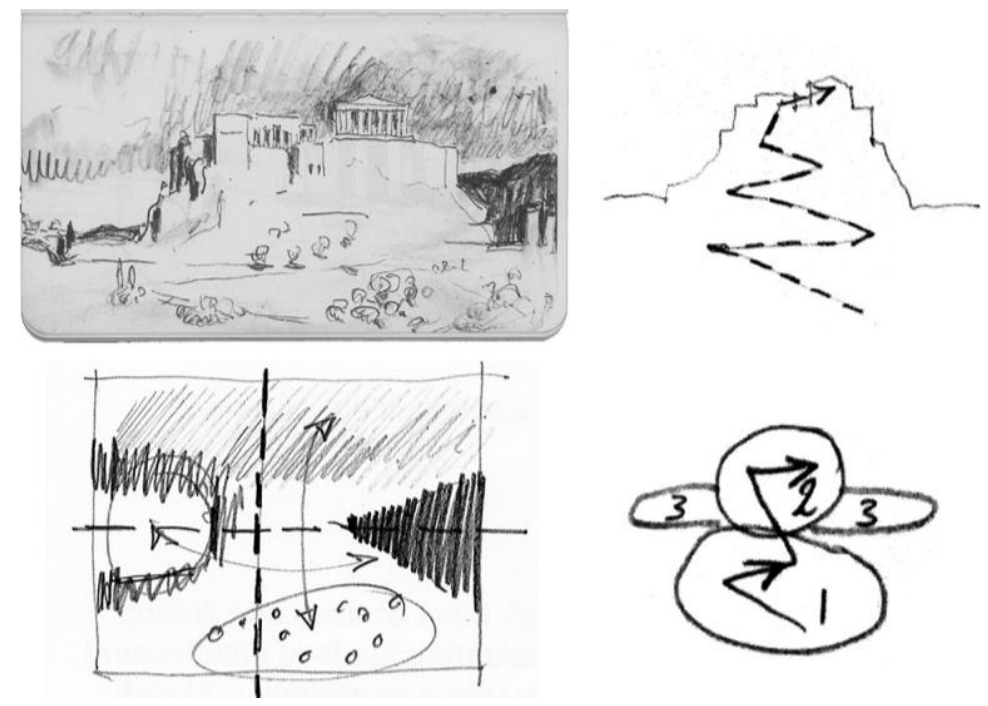

9. Clockwise from top left: Le Corbusier, Sketches 123, Carnet 3, Voyage d'Orient, 1911.; Schematic diagrams (SH) showing the visible pathway between viewer and the Parthenon; depths of field; balanced asymmetry of contrasting graphic techniques.

The complexity of the composition reaches its culmination in the final two in-situ Carnet sketches which emphasise the monumentality of the Acropolis (Sketch 123, figure 9) and the dynamic spatial arrangement of its individual buildings (Sketch 125, figure 10). Sketch 123 portrays the SW facade of the Acropolis and is in some respects similar to a zoomed out version of the Propylaea steps in 107 (figure 7). However, the treatment of the three depths of field transform it into a narrative journey describing the route towards the Parthenon. This distils Choisy's sequence of views into one single image and explains the logic behind the irregular arrangement of the buildings on the Acropolis.

The image shows a realistic spatial progression through continuous spatial regions, placing the viewpoint of the observer within the foreground on the path leading up and into the Acropolis. It also marks the progression through various architectural conditions from landscape to architecture integrated into the landscape at the Propylaea to the Parthenon totally separated from the ground by its plinth. The conceptual hierarchy of architectural elements emphasised graphically through the contrast of tone, texture and depth of field, culminating in the architectural and graphic climax of the Parthenon, raised and separated from the ground and dramatically silhouetted against the dark sky behind. This spatial continuity between viewpoint and building engages the viewer far more closely with the space of the picture than in the more abstract foreground spaces of the initial sketches ${ }^{35}$.

In sketch 125, The arrangement of three depths of field generates a directional sequence of spaces, rather than merely a contrast between different depths. As well as the continuous foreground, the asymmetrical composition balanced across a central axis and the contrasting depths of field dramatically overlapping one another, the sketch also uses an oblique viewpoint with the principle vanishing point positioned at the right of the picture. Apart from strengthening the contrast between architecture and horizon, the angled view of the building creates a diagonal axis across the page and through the Propylaea leading towards the distance ${ }^{36}$. This creates a visually

\footnotetext{
35 Alvaro Siza takes this idea further by drawing himself as the observer within the picture plane.

${ }^{36}$ Edmund Bacon calls this line a "shaft of space" referring to the area alined with the facade of the Temple of Hephaistos in the Agora below. Bacon, E.: Design of Cities. London: Thames and Hudson. 1967. pp.70-71.
} 
continuous path across the composition leading the eye into and through the spaces of the drawing and results in a far more dynamic image than a central axial viewpoint would allow, and helps to immerse the viewer in the space giving a clear direction of movement and spatial sequence.

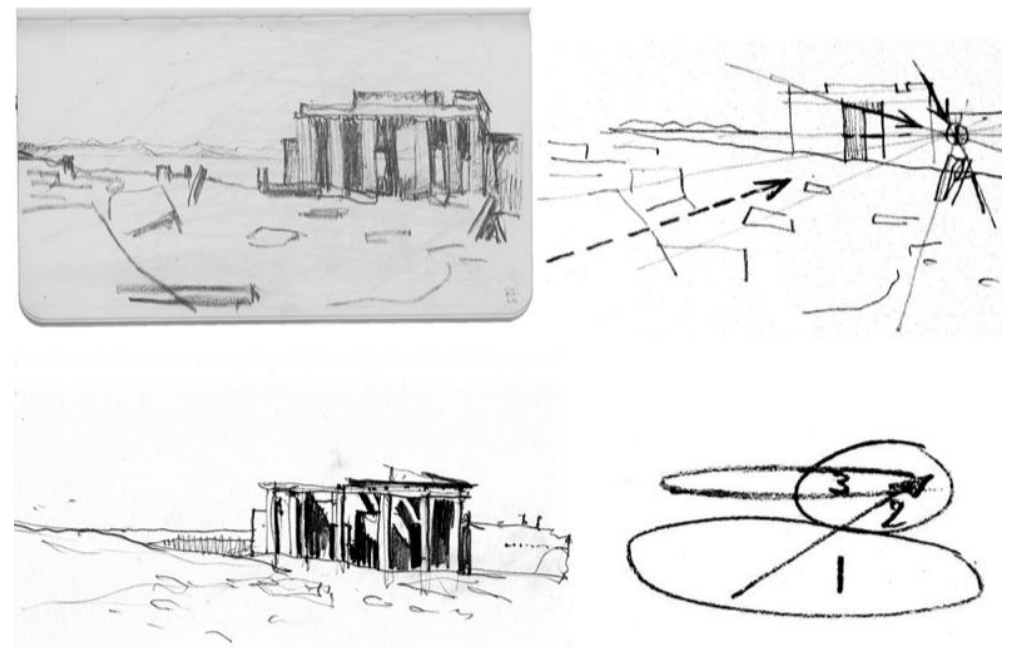

10. Clockwise from top left: Le Corbusier, Sketch 125, Carnet 3, Voyage d'Orient, 1911.; Schematic diagrams (SH) showing diagonal spatial composition; overlapping depths of field; and author's in situ sketch (2014) showing the city and Piraeus shaded to the left of the Propylaea (not drawn in Le Corbusier's sketch although it did exist as may be seen in photographs of the time ${ }^{37}$ ).

During the course of the sketches, Le Corbusier's own direct experience of the Propylaea came to change his initial understanding of it based on his prior knowledge. His sketches trace this change from initially depicting volumes and their relative positions to later exploring more emotive spatial qualities, using levels, light, depth and viewpoints to create a sense of movement through space within each picture.

\section{Conclusions}

This article demonstrates that Le Corbusier used his sketches as a structured method for his own personal investigation of the Acropolis and not just to illustrate pre-formed or borrowed concepts. I show that the Carnet sketches not only trace the path of discovery, but show how Le Corbusier was consciously using them to pathfind his conceptual way by means of trial and refinement. The sequential and systematic evolution of Le Corbusier's ideas shows that the sketches propelled and directed his train of thought. I find that the carnet sketches show a propositional approach to analysis focused on uncovering the principle questions underlying major features of the architecture, rather than purely recording the architectural solutions already stated by others. This method followed an intentional order but allowed him sufficient freedom to develop original interpretations of the Acropolis. This assisted him in transforming his prior knowledge of the Acropolis based on the theories of others into his own original interpretation of the architecture. More than just a record of what he discovered, these sketches reveal how he attempted to go about looking for it.

\footnotetext{
${ }^{37}$ See photographs and maps from Baedeker's guide to Athens, 1910, reproduced in Daza Caicedo, R., \& Quetglas, J.: Tras el viaje de Oriente : Charles-Édouard Jeanneret-Le Corbusier. Barcelona : Fundación Caja de Arquitectos. 2015
} 
In-situ, Le Corbusier's attention focused on the interface between ground architecture and horizon. This developed significantly during the course of the sketches and diverged into two alternative ideas, one of using steps and level changes to integrate architecture into the surface of the ground and another of using platforms and steps to separate and distinguish the architecture from the ground. The Carnet 3 shows that his appreciation of these relationships became broader and more complex during the course of the sketches rather than converging on one single concept.

The sequence shows that Le Corbusier's compositions developed from static picturesque depictions of the Acropolis to carefully constructed images which emphasised the dynamic experience of the viewer's movement through the architecture. As they proceed, the drawings convey an increasingly concentrated sense of movement through space. Diagonal viewpoints, asymmetric compositions and continuous spatial regions are all used to imply a variety of spaces related one to another and consequently implying the possibility of passage between them. The order of the views drawn in sketches 98 to 125 shows he was less interested in portraying a sequential fly-through or storyboard of the Acropolis, than in using the drawings as a means to analytically investigate the Acropolis.

In contrast to many texts about Le Corbusier's visit to the Acropolis, the sketches he made on location however make little mention of a number of issues which are considered by many authors to have been of central importance during Le Corbusier's revelatory first visit. This suggests that during his visit in 1911, Le Corbusier gave less importance to a number of his most celebrated ideas than is often assumed. Some of these, such as mathematical systems of proportion, material precision and "the plastic system brought together in light" developed only after his visit, with significant influence from other sources ${ }^{38}$ but were not immediately inspired by his in-situ experience of the Acropolis in person. Nevertheless, other ideas, such as the promenade architecturale, were formulated in-situ through gradual trial and revision in his sketches.

Le Corbusier used fast but expressive drawing techniques to represent fundamental architectural relationships and to most clearly reveal the primary effects that these produced on the observer. He used the compositions of the sketches and a variety of graphic techniques to emphasise his particular interests whilst minimising, or eliminating altogether, other aspects which were of only secondary importance to him at the time. The insistence on certain specific issues throughout the sketches, as well as the avoidance of others and the frequent poetic license in the representation of many views, show that these sketches were highly intentional interpretations of the Acropolis. The article finds that these interpretations became increasingly sophisticated as the sketches progressed and shows that he deliberately used his sketching as an active method to learn about the Acropolis.

Although inspired to great degree by the Acropolis, each sketch is in fact an individual and highly personal design project generated through the same propositional thought process Le Corbusier used in the design of his own built projects. The graphic analysis of these sketches reveals exactly how he went about finding and developing original interpretations of the most classic of architectural references. Le Corbusier's method of investigative sketching achieved particularly original results in the new interpretations which he extracted from such a well-known subject. It is also interesting to note the importance of these sketches in his later opinions, which he contrasted so directly and robustly with the dominant views of the time about the Acropolis ${ }^{39}$. In order to learn from this method, and understand how it may be replicated in other circumstances and used to maximum

\footnotetext{
${ }^{38}$ Frampton, K.: 2001. Op.cit.

${ }^{39}$ Corbusier, L.: Vers Une Architecture. Op.Cit. and Corbusier, L.: Precisiones respecto a un estado actual de la arquitectura y del urbanismo. Barcelona : Poseidón. 1978
} 
advantage today, this research has sought to explain in precise terms how Le Corbusier used the method, where he started from, what steps he took and how he reached his decisions.

The sketches are themselves evidence of a propositional mind with prior knowledge but without fixed preconceptions. Le Corbusier worked out his opinions and ways of seeing through using exploratory sketching to actively engage with his surroundings. This set of drawings demonstrates the initial phases of ideas which were later to become some of the determining characteristics of his work. As Jacques Lucan writes, on the Acropolis, "toute a commencé là...." ${ }^{40}$. The Acropolis sketches are the record of Le Corbusier's painstaking discovery of his most celebrated principles.

\section{Image Sources:}

Original 1911 sketches from Corbusier, Le.: Voyage d'Orient : Carnets. Milano : Mondadori. 2002 p98, p103, p104, p106, p107, p109, p111, p113, p115, p117, p119, p123, p125.

All other images and diagrams are by the author.

\section{Bibliographical References}

Baker, G: Le Corbusier - the creative search - the formative years of Charles-Edouard Jeanneret. New York: Van Nostrand Reinhold, 1996

Benton, T: The Rhetoric of modernism : Le Corbusier as a lecturer. Basel [etc.] : Birkhaüser. 2009

Brooks, A: Le Corbusier's Formative Years: Charles-Edouard Jeanneret at La Chaux-de-Fonds. Chicago: University of Chicago Press. 1999

Choisy, A: Histoire de l'architecture. Paris. 1899

Cohen, J.-L., Bergdoll, B., \& Pare, R.: Le Corbusier : an atlas of modern landscapes. London : Thames. 2013

Cohen, J.-L.: "Vers Une Acropole: d'Athènes a Ronchamp". In Le Corbusier - L'Invention d'un architecte Paris : Fondation Le Corbusier. 2014

Corbusier, L.: Precisiones respecto a un estado actual de la arquitectura y del urbanismo. Barcelona : Poseidón. 1978

Corbusier, L.: Voyage d'Orient : Carnets. Milano : Mondadori. 2002

Corbusier, L.: Le voyage d'Orient. Paris : Ed. Parenthèses. 1966

Corbusier, L.: Ed. Boesiger, W.: Oeuvre Complète. Paris : Éditions d'architecture. 1965

Corbusier, L.: Cohen, J.-L., \& Benton, T.: Le Corbusier le grand. London : Phaidon. 2008

Corbusier, L., \& Duboy, P.: Croquis de voyages et études. Paris : Quinzaine littéraire - Louis Vuitton. 2009

Corbusier, L.: Vers Une Architecture. Paris. 1923. Reprinted as Towards a new architecture. London :

Architectural Press. Translation by Etchells, F. 1987

Corbusier, L., Moos, S. von, \& Rüegg, A.: Le Corbusier before Le Corbusier : applied arts, architecture, painting, photography, 1907-1922. New Haven [etc.]: Yale University Press. 2002

Daza Caicedo, R., \& Quetglas, J.: Tras el viaje de Oriente : Charles-Édouard Jeanneret-Le Corbusier. Barcelona : Fundación Caja de Arquitectos. 2015

\footnotetext{
${ }^{40}$ Lucan, J.: Op.cit
} 
Fondation Le Corbusier. Rencontres, Amirante, R., \& Corbusier, L.: L'Invention d'un architecte : le voyage en Orient de Le Corbusier. Paris : Éditions de la Villette. 2013

Frampton, K.: Le Corbusier. London : Thames and Hudson. 2001

Lucan, J. : Le Corbusier : une encyclopédie. Paris : Centre de Création Industrielle. 1987

Moos, S. von. Le Corbusier : elements of a synthesis. Rotterdam : 010 Publishers. 2009

Quetglas, J : Les Heures Claires. Barcelona : Massilia. 2008

Thompson, D. Wentworth: On Growth and Form. Cambridge : Cambridge University Press. 1961 (abridged edition) 